\title{
Research Paper A study on marketing of marigold in western Maharastra
}

See end of the paper for authors' affiliations

Correspondence to :

\section{R.A. KOLAMBKAR}

Department of

Agricultural Economics,

College of Agriculture,

Vasantrao Naik

Marathwada Krishi

Vidyapeeth, PARBHANI

(M.S.) INDIA

Email: kolambkar.rachana

14@gmail. com

Paper History :

Received : 11.02.2014;

Revised : 20.06.2014;

Accepted: 07.07.2014
ABSTRACT : The study pertained to Kolhapur and Sangli districts of Western Maharashtra where marigold is cultivated extensively. The studty examined various economic aspects of marigold such as assessment of price spread, producer's share in the consumer's rupee, marketing cost and margins, marketing practices, channels involved in the marketing of marigold and problems faced by the growers in marketing of marigold. A sample of thirty farmers each were drawn from six randomly selected villages in the Hatkanangale tehsil of Kolhapur and Miraj tehsil of Sangli, total sixty sample farmers were selected for the study. Following Three marketing channels were identified in the study area for marketing of marigold - Channel I: Producer - Commission agent - Wholesaler - Retailer - Consumer. Channel II: Producer - Wholesaler - Retailer - Consumer. Channel III: Producer - Consumer Among these channels, 33.29 per cent quantity of marigold moved through channel- I, 41.77 per cent through channel- II and 24.93 per cent through channel- III. Marketing cost in the sale of marigold was Rs.684.03, Rs.400.13 and Rs.40.42 per quintal in channel-I, channel- II and channel- III, respectively. As such marketing cost was lower in channel- III and higher in channel- I. Marketing margins earned by the different agencies were highest in the channel- I (Rs.390.19 per quintal) and it was lowest in channel- II (Rs.277.53 per quintal). The producer's net share was maximum in channel- III (100 per cent) and minimum in channel- I ( 85.74 per cent) which was favourable to the producer. Out of all farmers, 95.00 per cent reported the problem of higher commission charges followed by delay in payment, high cost of transportation, lack of skilled labour for grading of flowers and lack of information of market prices in the study area.

KEY WORDS : Marketing, Marigold, Disposal, Price spread

HOW TO CITE THIS PAPER : Kolambkar, R.A., Suryawanshi, R.R., Shinde, H.R. and Deshmukh, K.V. (2014). A study on marketing of marigold in western Maharastra. Internat. Res. J. Agric. Eco. \& Stat., 5 (2) : 143-147. 